Maarit Forde \& Yanique Hume (eds.), Passages and Afterworlds: Anthropological Perspectives on Death in the Caribbean. Durham NC: Duke University Press, 2018. 297 pp. (Paper US\$26.95)

The eleven contributors to this edited volume on death provide a much needed region-wide survey of the relations and transformations catalyzed by "deathworlds" and their attendant mortuary and spiritual practices in the Caribbean. While nine of the chapters present particular cases that cumulatively provide good coverage of insular and coastal Caribbean societies, the work of presenting a truly regional perspective on common themes falls (as usual for edited volumes) to the introduction (Maarit Forde) and the afterword (Aisha Khan).

Despite the origins of the essays in a three-day workshop, each contributor presents their ethnographic case in isolation from the other chapters, and so the overall effect tends toward a cacophony of differing theoretical and ethnographic concerns. Perhaps this is a fitting metaphor for the region, or perhaps a missed opportunity. While each chapter is substantial enough to stand alone, the effect of turning the page to a new chapter could be jarring as authors talked past each other. In particular, George Mentore's perspectivist meditation on generalized and seemingly eternal Amerindian principles of "vital spirits," in which the meaning of individual deaths is divorced from questions of social power, stands isolated amid the currents of social change in highly pluralistic Caribbean societies.

Forde's introduction instead seeks the common ground. She invokes the shared context of the Caribbean's violent history of colonialism and slavery and its contemporary legacy in political repression and savage inequalities, arguing that the resulting issue for ethnographers of the region is the ethics of representing alterity. She argues that the anthropology of death has long reinforced the otherness of those studied, denying coevalness for the dead and those who mourn them. And she calls for positioning alterity as a research problem.

A related common theme of the volume is the need to address the question of how the politics of death serves to reproduce - and sometimes challengeinequalities among the living, especially insofar as deathways implicate forms of personhood and historical memory. Richard Price productively compares colonial-era Saamaka stoicism under torture and execution by the slavocracy to Saamakas' contemporary practices involving similarly severe techniques of "total power" for producing justice through suffering. Ineke van Wetering and Bonno Thoden van Velzen describe ancestor cults in contemporary Ndyuka society as a locus of conflict between different generational and gendered 
claims on moral authority. And Forde's chapter introduces a "thanatopolitics" to accompany the "biopolitics" of policing "good" versus "bad" forms of death and the dead in Trinidad and Tobago.

Khan's afterword, too, highlights issues of power in representing death and its rituals and suggests that scholars expand the kinds of data about death and afterworlds as a horizon beyond direct phenomenological experience. It is not clear that the assertion that death is beyond our (whose?) phenomenological experience and knowledge is valid: even the example she gives-oddly enough, Dickens's "A Christmas Carol"-indicates that not all of "us" find death and the dead to be phenomenologically inaccessible. In this light, consider Paul C. Johnson's analysis of how Garifuna ritual traditions facilitate two contrasting modes of ancestral presence, which he calls the "transmissive" and "emissive" and which might represent a broader principle in the Caribbean regarding the phenomenology of copresence.

Khan also points out the ways in which this volume's many cases of death and its rituals exceed the category of "religion." Certainly, death mobilizes social and even political change, as in Keith E. McNeal's case of the "spectacular iconicity" of mortuary practices in Trinidadian Hindu ethnonationalism, and Donald Cosentino's account of the shifting prominence of death as personified by the lwa Baron Samedi and the Gede in Haiti, especially in confronting the sheer scale of death after the 2010 earthquake.

As these contributions amply demonstrate, suffering and social struggle often play out in the theater of practices surrounding and confronting death. Death marks a passage but not a transition out of sociality and the business of living. The chapters by Yanique Hume and Karen Richman reconsider Arnold van Gennep's "rites of passage" and Victor Turner's "social drama" to bring out different implications for Jamaican and Haitian mortuary rituals. For Hume, home-based ceremonies "root" Black Jamaican struggles for sovereignty through land tenure. And for Richman, Haitian ceremonies that maintain communication with the deceased as they transform into ancestors demonstrate an unresolved struggle to find meaning in suffering.

This volume provides ample material to Caribbeanists and those interested in the anthropology of death, including as reading to assign to undergraduate and graduate courses alike.

\section{Kristina Wirtz}

Department of Spanish, Western Michigan University kristina.wirtz@wmich.edu 